Ankara Ecz. Fak. Mec.

5. 144. (1975)
J. Fac. Pharm. Ankara

5. 144. (1975)

\title{
Türkiye'de İmal Edilen Hidrofil Pamuk ve Cerrahi İpek İpliklerin Kaliteleri Üzerinde Araştırma
}

\author{
Investigation of the Quality of Absorbent Cottons \\ and Surgical Silk Sutures Made In Turkey
}

Enver İGÜ̈ Necati DiKMEN** Namik EVREN***

Türk Farmakopesi 1974 (1) Hidrofil Pamuk monografisinde "Gossypıum Depuratum» Latince adı altında șu tarifi yapmıștır: «Hidrofil Pamuk, Gossypium nevilerinin (Malvaceae) tohumları üzerinde bulunan, yağından kurtarılmış, temizlenmiş liflerdir.s

1974 Türk Farmakopesine (1) Cerrahi İplikier monografi olarak henüz alınmamıștır.

Avrupa Farmakopesi (2), Alman Farmakopesi (3), Amerikan Farmakopesi (4), Avusturya Farmakopesi (5), Fransız Farmakopesi (6), Ingiliz Farmakopesi (7), İsviçre Farmakopesi (8), Hidrofil Pamuk ve Cerraî İplikleri monografi olarak almıșlar ve vasıflarını değișik ölçülerde belirlemişlerdir.

Türk ve Amerikan Farmakopeleri (1) (4) yalnız hakiki pamuğu kabul etmiș iken hemen diğer Farmakopeler (2, 3, 5, 6, 7, 8) -Sellülozdan değişik kimyasal ișlemlerle (15) elde edilen (yapma-sun'i) pamuğu da monografi olarak almıșlardır.

Hidrofil pamuğun tıpta ve en çok cerrahide gördüğü vazife önemlidir. Hidrofil Pamuktan beklenen bir çok özellikler vardır. Örneğin, yumușak destek, tampon, emici olma, taşıyıcılık, koruyuculuk gibi. Bütün bu görevleri yaparken de organlara ve ișlemlere zarar vermemelidir.

Redaksiyona verildiği tarih : 8. Mayıs. 1975

- Gülhane As. Tıp Akademisi ve Farmakognozi ve Galenik Farmasi Kürsüsü, Eczacılık Fakültesi, Ankara Üniversitesi.

* Gülhane As. Tıp Akademisi 
de edemediğimiz için karşılaştırma ile bir yapı ispatına gidilemedi. Onun için aletsel analizleri yaplarak elde edilen spektrumlar incelendi.

UV Spektrumu : Maddenin 200-400 $\mathrm{m} \mu$ dalga boyları arasında yapilan absorbsiyon spektrumunun (spektrum 10) incelenmesinde, $312 \mathrm{~m} \mu, 261 \mathrm{~m} \mu, 254 \mathrm{~m}$, $288 \mathrm{~m} \mu$ ve $244 \mathrm{~m} \mu$ dalga boylarinda maksimum; $238 \mathrm{~m} \pi$ ve $275 \mathrm{~m} \mu$ dalga boylarındada minimum absorbsiyon göstermektedir. Bu pikler bize molekül II bağ sisteminin varliğını belirtmektedir. $224 \mathrm{~m} / \mathrm{t}, 228 \mathrm{~m} \mu$ ve 254 mu dalga boylarında ki maksimum pikler özellikle aromatik konjugasyonu vermektedir. $(2,3,20)$.

IR Spektrumu: Molekülde mevcut fonksiyonel gruplarn varlı̆̆ 1 tespit edilen șu pikler ile ortaya çıkt. (Spektrum 11) $3475 \mathrm{~cm}^{-1}$ deki kuvvetli band serbest hidroksil gruplarin, $3333-3225 \mathrm{~cm}^{-1}$ de görülen band ise amin gruplarmın varhğını ortaya koymaktadır. $1192 \mathrm{~cm}^{-1}$ deki pik tersiyer hidroksili, $1250-1300 \mathrm{~cm}^{-1}$ deki kuvvetli pikler sekonder, $1162 \mathrm{~cm}^{-1}$ tersiyer ve $1086 \mathrm{~cm}^{-1}$ deki kuvvetli pikler de primer amin gruplarinın varlığını göstermektedir. $A_{1}$ de görülmeyen ve $755 \mathrm{~cm}^{-1}$ ile $1400-1600 \mathrm{~cm}^{-1}$ deki kuvvetli dallanmış pikler disübstitüe aromatik halkanın moleküldeki varlığını doğrulamaktadır. $1700 \mathrm{~cm}^{-1}$ civarında tespit edilen derin bir pik moleküldeki karbonil absorbsiyonunu vermektedir. $(2,3,16,17$, $18,19)$

NMR Spektrumu : Maddenin elementer analiz ve Mass spektrumu ile tespit edilen kapalı formülïndeki protonlarin karakterleri hakkında kesin fikir edinmek üzere yaptırılan NMR Spektrumunun incelenmesinde şu neticeler elde edilmiştir (Spektrum 12). Yapilan entegrasyon hesabında tespit edilen sinyallerin, 53 protona tekâbül ettiği gösterilmektedir. $6.98-8 \mathrm{ppm}(\sigma)$ arasında elde edilen sinyaller, aromatik grubu göstermektedir. 5.9 _ $6.1 \mathrm{ppm}(\sigma)$ arasındaki geniș sinyal bir protona tekâbül etmektedir. Bu protonun özellikle aromatik halka ile üzerinde karbonil grubu tașiyan bir karbon atomuna bağlı sekonder amin hidrojenine tekâbül ettiği düşünülmektedir. $3.7-4.3 \mathrm{ppm}(\sigma)$ arasında görülen sinyaller iki serbest hidroksil hidrojenlerini vermektedir, 0.83 ile $3.6 \mathrm{ppm}(\sigma)$ arasında elde edilen bir çok sinyal entegrasyonla hesaplanan 34 
tée d'ammoniaque avant de subir une percolation par le benzéne. On obtient ainsi un extrait total des alcaloides de la racine. La chromatographie sur couche mince nous a révélé l'existence de six alcaloides dans cet extrait. A partir de celui-ci, deux des six alcalo: des ont été obtenus cristallisés. Aprés isolement, ces deux substances on fait l'objet d'une étude plus approfondie permettant leur identification rendue possible par le anlyses suivantes: point de fusion, pouvoir rotatoire, hydrolyse alcaline et hydrolyse acide, obtention des sels et dérivés acétylés, puis par analyses plus prescises telles que; spectre de masse, spectre UV, spectre IR et spectre NMR on a ainsi mis en évidence la présence de lycoctonine et de delsemine dans les racines de Delphinium formosum, alcaloides déja trouvés dans d'autres espéces de Delphinium.

Les dosages ont été pratiqués sur les racines de la plante selon la méthode indiqucé par la Pharmacopée Internationale pour les alcaloides des Aconits. Les résultats nous ont donnés $2.08 \%$ d'alcaloides calcules en delphinine et $2.42 \%$ d'alcaloides calculés en delsemin. On trouvait $2.7 \%$ d'alcaloides totaux par dosage gravimetrique.

La détermination de la dose léthale a été pratiquée sur la souris par injection intrapéritonéale et on a trouvé une $\mathrm{DL}_{50}$ de $37.4 \mathrm{mg} /$ kg pour la delsemine.

\section{I T E R A T Ü R}

1) Cook, W.B., and Beath, D.A.: The alkaloids of D. barbeyi H., J. Am. Chem. Soc. 74, 1411 (1952).

2) Dyer, J.R.: Spectroscopie d'absorption appliquée aux composées organiques Dunod Paris (1967).

3) Ewing, W.G.: Instrumental Methods of chemical Analysis II. Ed. (1960).

4) Cheorghiu, A., lonescu - Matiu, E. et Manuchian, M.: Contribution a l'étude pharmacognosique du Delphinium consolida L.; Ann. Pharm. Franç. 22, 49-57 (1964).

5) Goodson, J.A.: The alkaloids of the seeds of Delphinium elatum L., J. Chem. Soc. 139. (1943).

6) Goodson, J.A.: Delphinium alkaloids, Part II ajacine, J. Chem. Soc, 108 (1944)

7) Holubek, J. and Stroue, O.: Spectral date and physical constans of Alkaloids. 360, Heydan and son limited. London Praque (1969). 
8) Kuder, R.C.: Larkspure, Delphiniums and chemistry, Physiological action of Delphinium alkaloids. J. Chem, Education 24, 418. (1947).

9) Manske, R.H.F., Holmes, H.L. : The alkaloids chemistry and Physiology. Academic Press İnc. N. Y, vol, XII (1970).

10) Manske, R.H.F., Holmes, H.L.; The alkaloids chemistry and Physiology Academic Press ínc. N.Y. Vol. IV (1954).

11) Marion, L., and Edwards, O.E.: The alkaloids of D. consolida L., J. Am. Chem Soc. 69, 2010 (1947).

12) Marion, L., and Manske, R.H.F., : Identity of the hydrolytic base obtained from D. brownii Rydb, with lycoctonine. Canad. J. of Research. Vol 24 Sec. B 1-4 (1946).

13) Miana, G.A., Israr Khan, M. Fehmi da Sultana and İram, M.: The alkaloids of Delpinium vestitum Wall. İsolation and characteristation of lycoctonine Pakistan J. Sci. İnd. Res. 13 51-52 (1970).

14) Pelletier, S.W., Teith, L.H., and Parthasarathy, P.C.: The structures of Condelphine, Isotalatizidine and talatizidine. J. Am. Chem. Soc. 89 (16), 4146-57 (1967).

15) Przyborowska, M.: Ckromatographie separation of alkaloids from the flowers of Consolida regalis. Dissertationes Pharm. 17 (4), 497 (1965), Ref: C.A. 67, $18001 \mathrm{~g}$ (1966).

16) Schneider, W.: Aconitum Alkaloide. Chemische Berichte. 89, 768 (1956).

17) Schneider, W.: Aconitum Alkaloide. Chemische Berichte 89, 762 (1956).

18) Schneider, W.: Aconitum Alkaloide. Naturwissenschaften. 44, 512 (1957).

19) Schneider, W.: Die Struktur des Diterpenalkaloides Delphinin Arch. Pharmazie 293/65, 577 (1959).

20) Schneider, W.: Aconitum Alkaloide. Liebigs Ann. Chem. 628, 114 (1959).

21) Yunusov, S., and Abubakirov, N.K.: The alkaloids of D, semibarbatum. Doklatdy Akad. Nauk Üzbek, S.S.R. (No. 8) 21-5 (1945), Ref. C.A. 4812755 c (1954).

22) Yunusov, S., and Abubakirov, N.K.: Alkaloids of the Ranunculaceae family V Alkaloids of D. oréophilum. Zhur. opshchei Khìm, (J. Gen. Chem) 21, 967, (1951) Ref. C.A., 46516 g (1952).

23) Yunusov, S., and Abubakirov, N.K.: Alkaloids of Delphinium semibarbatum IV. delsemidine zhur. Obschei. Khim. (J. Gen. Chem.) 22, 1461 (1952) Ref. C.A., $477515 \mathrm{i}$ (1953).

24) Yunusov, S., and Abubakirov, N.K.: Alkaloids of Delphinium semibarbatum IV. alkaloids of Ranunculaceae. Zhur obshchei. Khim. (J, Gen. Chem.) 21, 174-48 (1951) Ref. C.A., 455366 a (1951). 
D. formosum Boiss et Huet, bugün Türkiye'nin doğu bölgesinde halk arasinda gayet yaygin olarak $D$, ajacis L. D. consolida ve $D$. staphisagria L. gibi ayn gayelerle kullanılan bir Delphinium türüdür.

Tașıdıkları toksik alkaloitlerden dolayı Delphinium türlerinin zehirlenmelere sebep olduğu bilinmektedir. Biz bu nedenle $D$. forfosum Boiss et Huet, alkaloitlerinin kimyasal yapısını aydınlatabilmek, ayrica drog olarak kullanilan diğer türlerle mukayesesini yapabilmek gayesi ile çalıșmalarımızı yürüttük.

İzole ettiğimiz iki alkaloitten birinin, daha önceleri $D$. semibarbatum Bien, ve $D$. orephilum $\mathrm{H}$, den izole edilen delsemin ile, diğerinin ise Aconitum Leveille et Vaniot, A. Jycoctonum L, $D$. elatum L, D. consolida L, D. barbeyi $\mathrm{H}, D$. ajacis L, D. brownii Rydb, D. semibarbatum Bien, D. oreophilum H, Inula royleana D.C den izole edilen likoktonin ile idantik olduğunu gördük.

Yapilan tüm alkaloit miktar tayininde titrimetrik yolla $D$, formosum'un toprak toprak altı kısımları için delsemin üzerinden hesaplanarak bulunan miktar \% 2,42 dir. Gravimetrik yol ile ise $\% 2,7$ bulunmuștur. Yine gravimetrik yol ile yapılan delsemin ve likoktonin miktar tayinine göre delsemin için bulunan miktar \% 0.7 likoktonin için bulunan miktar \% 0,09 dur. Görüldügüu gibi $D$, formosum alkaloit yönünden oldukça zengin bir bitkidir.

Likoktonin bir alkamin olduğu için ester alkaloitlerine nazaran toksisitesi üzerinde durulmayacak kadar önemsiz olduğu eski. den beri bilinen bir gerçektir.

Delphinium alkaloitlerinin toksisitesine, deney hayvanınin sicak ya da soğuk kanlı olușu büyük ölçüde etkì eder. Delsemin için tarafımızdan yapılan toksisite kontrolünde ise farelerde LD $_{50} 37.4$ $\mathrm{mg} / \mathrm{kg}$, olarak bulunmuștur. Hallulli en cok tanınan Delphinium alkaloitlerinden biri olan ve $D$. staphisagria L, den elde edilen delfinin için $\mathrm{LD}_{\mathrm{s0}}$ kurbağalarda $0.1 \mathrm{mg} / \mathrm{kg}$ dir.

Ayrıca delsemin gibi likoktonin iskeletine sahip olan ve kimyasal yapı itibarı ile delsemin'e çok yakınlık gösteren ve Aconitum 
Bu özellikleri en iyi olarak hakiki pamuğun taşıdığı asırlarca kullanılarak kanıtlanmıștır. Ancak gelișmiș memleketlerin -Amerika Birleşik Devletleri hariç- hemen hiç birinde pamuk ürememektedir. Çünküi, pamuk genellikle Ekvatorun 40 enlem așağı yukarısina kadar olan bölgelerde üremektedir.

$\mathrm{Bu}$ bakımdan o memleketlerce pamuğu daima ithal mecburiyeti vardır. Bunun anlamı da -her alanda olduğu gibi- kendi istihsalleri olmayan malm pahalı gelmesidir.

Bundan dolayı pamuk yerine kullanılabilecek sentetik maddelere yönelerek Selliulloz'dan benzer özellikte bir madde elde etmeye gayret edilmiş ve Sellüloz Pamuğu denilen Pamuk benzeri yapilmıștır.

Geri kalmış ve gelișmekte olan memleketlerin kaderi de daima ve anlam üzerinde fazla durmadan taklit ve etki altunda kalma olduğundan memleketimizde de Pamuk yerine ve özellikle Hidrofil Pamuk yerine Hidrofil Selluloz Pamuğu yapma ve kullandirma özentisi duyulmuș ve bu yönde teșebbüse geçildiği saptanmıștır.

Türk Farmakopesinde (1) olmayan bu tıbbî malzemenin -ofisinal olarak kullanılabilmesi kanunen mümkün değildir.

Buna rağmen piyasaya ve hastanelere -yapma- Selluloz Pamugunun verildiği ve sürüldügü görüldüğünden bir piyasa kalite araștirması düzenlenmiştir.

Hidrofil pamuk nasil memleketimiz ürünlerinden elde ediliyor ise İpek İplik te memleketimiz ürünlerinden elde edilmektedir. Ancak, Cerrahi sütür olarak, gelişmiş memleketlerde yalnız İpek İplik değil, Keten, Pamuk (4), Nylon (2) ve Poliester ipliklerde kullanılmaktadır, Memleketimizde en çok ipek cerrahi iplik kullanıldrğından Türk Malı Cerrahi İpek İpliklerinde durumunu tesbit için bunların da piyasa -kalite arastırmasını aynı çalıșmada yürüttmey? uygun bulduk.

\section{Calıșmanin Amacı :}

Türkiye'de imâl edilen Hidrofil Pamuk ve Cerrahi İpek İplik lerin kalitesinin, ve hangi yabancı katkı maddeleri ile ve ne orar larda karıştırıldığının, çeşitli metodlarla saptanması ve karıșı 
cerrahi malzemelerin ekonomik ve klinik yönden anlamlarınır tartışılmasıdır.

\section{MATERYEL VE YÖNTEM}

I - Așağıdaki pamuk kategorileri üzerinde araștırma yapıl mıștır.

A - Devlet müesseselerine mubayaa edilen ve edilmiș pamuklar.

a) Türk Silâhlı Kuvvetlerine mübayaa için satın alın madan evvel Gülhane Askerî Tıp Akademisine mu ayeneye gelen pamuklar.

b) A. Üniv. Tıp Fakültesine mubayaa için satın alın madan evvel Gülhane Askerî Tup Akademisi'n muayene için gönderilen pamuklar.

c) S.S.K. Hastanelerine ve Hacettepe Hastanelerinє mubayaa edilmiş -alınmış ve kullanılmakta olan pamuklar.

B - Serbest Eczanelerde ve Ecza Depolarında satılan Pa muklar.

Üzerinde çalıșılan bütün pamuklar numaralanarak Tablo 1' de gösterilmiștir.

Tablo 1

\begin{tabular}{c} 
Numune \\
\hline 1 \\
3 \\
3 \\
7 \\
5 \\
13 \\
7 \\
8 \\
0 \\
30 \\
11
\end{tabular}

Numunenin Alındığı Veya Geldiği Yer

Markas

A. Ü. Tıp Fakültesi Dekanlığı

A. Ü. Tıp Fakültesi Dekanlığı

Ank. Lv. A. Mua. Kom. Gen. Bșk. lığı

Ank. Lv. A. Mua. Kom. Gen. Bșk. lığı

Yüksek İhtisas Hastanesi Eczanesi

Hacettepe Tıp Fakültesi Ameliyathanesi

Sigorta Hastanesi Ecza Deposu

Tıp Fakültesi Hastanesi Eczanesi

Yenimahalle'de Eczaneden

(R)

Yenimahalle'de Bakkaldan

(A)

Yenimahalle'de Bakkaldan

(K) 
Yenimahale'de Eczaneden

Yenimahalle'de Eczaneden

Yenimahalle'de Eczaneden

(AL

Bakanlıklarda Eczaneden

Bakanlıklarda Bakkaldan

Bakanlıklarda Bakkaldan

Bakanlıklarda Bakkaldan

Anittepe'de Eczaneden

Anittepe'de Eczaneden

Anıttepe'de Bakkaldan

(i)

(H

(I)

13

II - Așağıdaki Cerrahi İpek İplikler üzerinde araştırma yapılmiştır.

a) Türk Silâhlı Kuvvetlerine mubayaa için satın alınmadan evvel Gülhane As. Trp Akademisine muayeneye gönderilenler.

b) Sağlık ve Sosyal Yardım Bakanlığının -çalıșmamızı ișitmesi üzerine piyasadan alarak bize kontrol için gönderdiği numuneler.

c) Ŭniversite ve Devlet Hastanelerine satın alınmıș ve kullanilmakta olan Cerrahi İpek İplikler

d) Piyasadan alınan

(Not: Pamuk ve İpek İpliklerin, Firma adları bilimsel geleneklere uyularak açıklanmamıș ve her marka bir harf ile gösterilmiștir. C.G.E.T. gibi).

\section{YÖNTEMLER :}

Pamuklarda kontrollar, evvelâ Türk Farmakopesine (1)'e göre, burada bulunmayan Selluloz - (Viskoz) - pamuğu aranması, Alman Farmakopesine göre (4) ve yüzey etken maddeler -Avrupa Farmakopesine (2) ve Fransız Farmakopesine $(6,16)$ göre yapılmıștır. Tablo 2. Değişik Farmakopelerdeki Hidrofil Pamuk Kontrol metodlarını göstermektedir. 


\begin{tabular}{|c|c|c|c|c|c|c|c|}
\hline 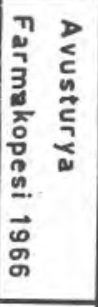 & 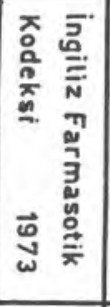 & 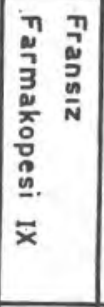 & 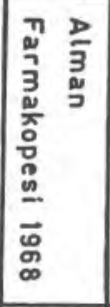 & 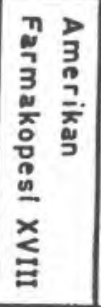 & 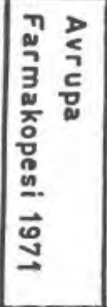 & 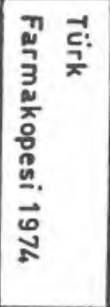 & 少 \\
\hline+ & + & + & + & + & + & + & $\begin{array}{l}\text { Asitik } \\
\text { Alkalenlik }\end{array}$ \\
\hline+ & ' & 1 & + & - & ' & + & $\begin{array}{l}\text { Klorür, Sulfat, Kalsiyum } \\
\text { Redüktör madde }\end{array}$ \\
\hline+ & + & $T$ & + & + & + & + & Yag maddeleri \\
\hline+ & + & + & 1 & + & + & + & Boyar maddeler \\
\hline+ & + & + & + & + & + & + & Kül miktarı \\
\hline+ & + & + & + & + & + & + & Suya batma hizı \\
\hline+ & + & + & + & + & + & 1 & Su tutma kapasitesi \\
\hline+ & + & + & ' & । & + & + & Nem miktarı \\
\hline+ & + & + & + & 1 & + & 1 & Fluoriesans \\
\hline 1 & + & + & $\cdot$ & 1 & + & 1 & Sert yumakçık \\
\hline+ & + & + & + & + & + & 1 & Kuru artık \\
\hline ' & + & + & + & ' & + & ' & Yüzey etken maddeler \\
\hline ! & + & + & 4 & + & + & 1 & $\begin{array}{l}\text { Mikroskopta Lif tipi } \\
\text { Tayini }\end{array}$ \\
\hline 1 & 1 & i & 4 & 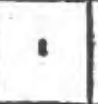 & 1 & 1 & $\begin{array}{l}\text { Selluloz pamugu } \\
\text { Arama }\end{array}$ \\
\hline ' & ' & - & - & + & । & ' & Lif Uzuntug̃u \\
\hline+ & ' & I & 1 & 1 & 1 & 1 & $\begin{array}{l}\text { Bakır Sayısı } \\
\text { (Hidroselloloz M.T) }\end{array}$ \\
\hline
\end{tabular}


Viskon - Selluiloz Pamuğu Tayini :

A - Mikroskopta. Şekil 1.

Pamuk : Düz fakat tek biçim olmayan uzunluğuna bükümlü lifler.

Viskon: Bükümsüz, düz uzunluğuna çizgili lifler, beyazlatılmislarda noktalı benekler görülüi

Sekil. 1. Pamuk ve Viskonun Mikroskopta görünüșũ

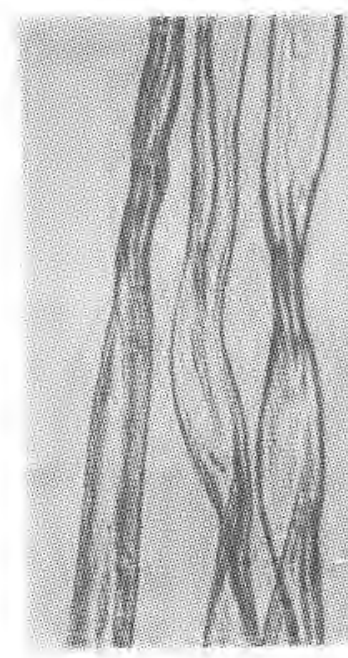

a

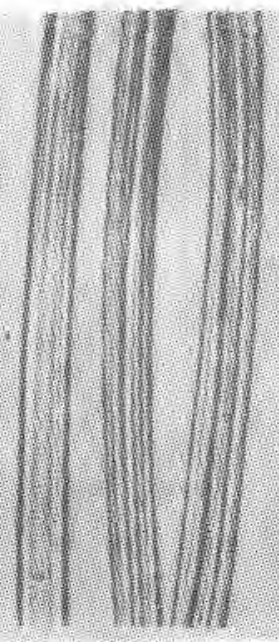

b

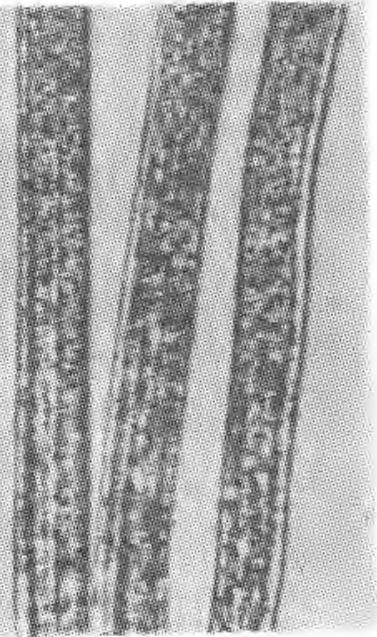

c

\section{B - Kimyasal :}

$105^{\circ}$ de kurutulmus pamuk -hassas olarak tartilir ve $40^{\circ} \mathrm{C}$ sıcaklıktaki $50 \mathrm{ml}$. Çinko Klorür -Formik asit çözeltisi içersine atılır, kuvvetle çalkalanır ve 2,5 saat tutulur. Cam filtreden süzülür -yıkanırartık- pamuktur, Kurutulur ve tartilir.

Yüzey Etken Maddeler Aranması (2): $10 \mathrm{~g}$, pamuk kapalı bir kapta 2 saat $100 \mathrm{ml}$. su içersinde birakılır. Bundan $10 \mathrm{ml}$. su aktarilarak bir tüpe alınır. Tüp kuvvetle çalkalanır ve 10 dakika bekletilir, meydana gelen köpük 10 dakika sonunda 1 mm. kalınlıktan veya suya temas yerinden daha yükseklikte olmamalıdrr. 
Cerrahi İpek İpliklerde Kontroller : Avrupa Farmakopesi (2) ve U.S.P. (4)'ye göre yapılmıștır. Bu Farmakopelerde bulunmayan -katkı iplik cinsleri- yani ipek iplikten bașka ipliklerin aranması Literatüre (9-14) göre yapılmış ve oranları da geliștirdiğimiz usule göre saptanmıștır. Tablo 3. Avrupa Farmakopesi ve U.S.P.'deki kontrol türlerini göstermektedir.

Tablo III

A. F. ve U. S. P.'ye göre

Absorbe olmayan cerrahi ipliklerdeki muayeneler

\begin{tabular}{|c|c|c|}
\hline & A. $F$. & U. S. P. \\
\hline Tanıma & + & \\
\hline Uzunluk & + & + \\
\hline Çap & + & + \\
\hline $\begin{array}{l}\text { Direnç (Kopmaya karșı) } \\
\text { a - Cerrahi düğüm ile } \\
\text { b - Basit düğüm ile }\end{array}$ & & + \\
\hline d - Sterilize edilmemiș & + & $\begin{array}{l}\text { (Sterilize edilmemiş ola- } \\
\text { rak elde edilen değerler- } \\
\text { den yüzde } 20 \text { indirerek } \\
\text { değerlendirme yapar.) }\end{array}$ \\
\hline $\begin{array}{c}\text { e - Gözsüz iğneye ta- } \\
\text { kılmıS }\end{array}$ & & $\begin{array}{l}+ \\
+\end{array}$ \\
\hline Sterilite & + & İcap ediyor ise \\
\hline $\begin{array}{l}\text { Ekstraksiyon ile alınabilen } \\
\text { boya }\end{array}$ & & + \\
\hline
\end{tabular}

TANIMA : Avrupa Farmakopesi İpek Cerrahi İpliği monografi olarak almış ve tanınması için iki usûl göstermiştir.

a) Mikroskobik tanıma

b) İyodlu potasyum iyodür çözeltisi $(2+4+100$ ml. su) ile açık sarı renk verir.

Direnç Testi : Pandüllü Shopper tipi alet ile yapılmıștır. İpliklerin otoklavlanmadan evvel $\left(121^{\circ} \mathrm{C} 30^{\prime}\right)$ ve otoklavlandiktan sonra -cerrahi düğüm atılarak dirençleri ölçülmüştür. 
Çap Ölçümü: Mekanik metodla ve Mauser Marka göstergeli çap ölçen aletle yapılmıștır.

Yabancı İplik (Elyaf) Aranması : Tablo 4'de görülen iplik cinsleri Literatürde bildirilen $(9,10,11,12,13,14)$ metodlara göre aranmıştır.

Tablo IV.

İplik Cinslerinin Saptanması

\begin{tabular}{|c|c|c|c|c|c|c|}
\hline & $\begin{array}{l}\text { Bakır Oksit } \\
\text { Amonyak }\end{array}$ & $\begin{array}{l}\text { Formik } \\
\text { asid } \% 90 \\
\end{array}$ & $\begin{array}{l}\mathrm{HCl} \\
\% \quad 37 \\
\end{array}$ & $\begin{array}{l}\mathrm{H}_{2} \mathrm{SO}_{4} \\
\% \quad 70 \\
\end{array}$ & $\begin{array}{l}\mathrm{NaOCl} \\
\% \quad \mathbf{5 . 2 5} \\
\end{array}$ & $\begin{array}{l}\text { Formik Asid } \\
\mathrm{ZnCl}_{2}+40^{\circ} \mathrm{C}\end{array}$ \\
\hline Pamuk & Çözünür & - & - & Çözünür & - & - \\
\hline Viskoz & Çözünür & $\longrightarrow$ & $A z$ çözünür & Çözünür & $\longrightarrow$ & Çözünür \\
\hline Yün & - & - & - & $\longrightarrow$ & Çözünür & $\longrightarrow$ \\
\hline İpek & - & & Çözünür & Çözünũr & Çözünür & 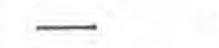 \\
\hline Dakron & $\longrightarrow$ & - & - & - & - & - \\
\hline Orlon & $\longrightarrow$ & & - & - & 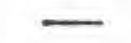 & $\longrightarrow$ \\
\hline Nylon & $\longrightarrow$ & Çözünür & Çözünür & Çözünür & $\longrightarrow$ & - \\
\hline Asetat & - & Çözünür & Çözünür & Çözünür & $\longrightarrow$ & $\longrightarrow$ \\
\hline
\end{tabular}

Yabancı Elyaf Oranı : İki usûlde yapılmıștır.

a) İplikler Hipoklorit içersinde tutulur -ipek kısımlar çözündükten sonra kalan kısım distile su ile yıkanır, kurutulur ve tartılır. Artık üzerinde ayrıca cins tesbiti de yapılır.

b) Memleketimizde Cerrahi İpek İpliklerin -yabancı elyafı ipekle karıștırarak değil- ipek dokulu kısım içersine - yabancı dokulu ipliği gömmek sureti ile tağşiş edildiğini saptadık. Bunun sonucu yabancı ipliği - ipek dokunun içinden çekmek sureti ile oranını tayin ettik. Şekil, 2. Șekil 3.

Mikroskobik Muayene : İlk ayırımı yapmak üzere lifler mikroskopta kontrol edildi.

İpek; Pürüzsüz yüzeyli fakat tek biçim olmayan lifler, uzunluğuna bükümlü görüinüss.

Dakron ve Nylon; Pürüzsüz yüzeyli, tek biçim ve çizgisiz lifler.

Asetat ve Viskoz Reyon; Uzunluğuna ve birbirini kesmeyen çizgili lifler. 


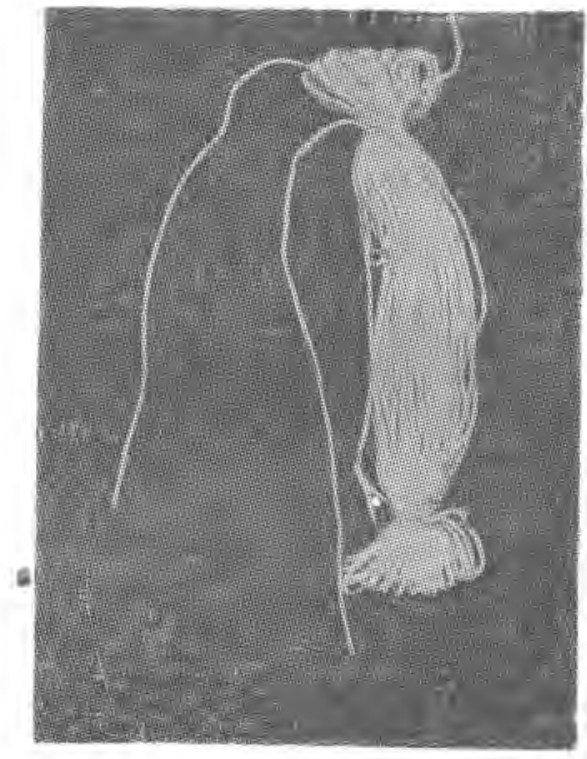

Șekil 2.

C̣özünme ile ayırma

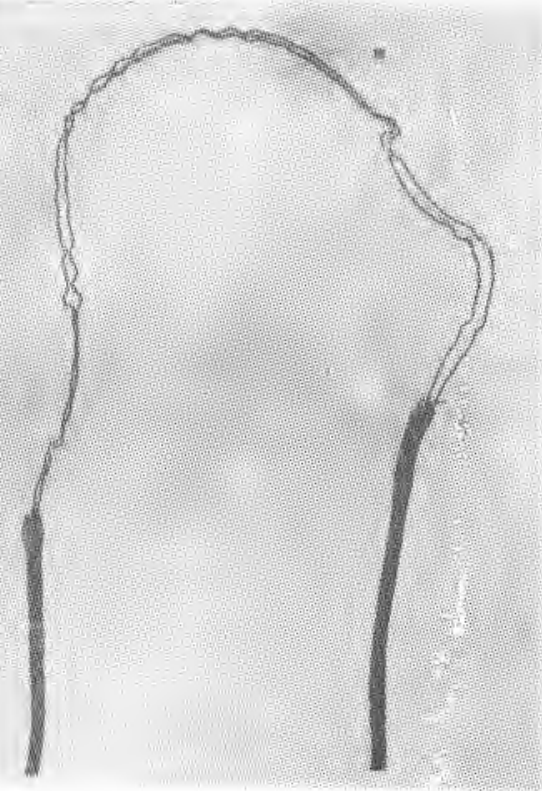

Sekil 3.

Çekerek ayırma

Kılcallkk Tayini : Bu tayin U.S.P. 18 ve A.F. 1972'de yoktur. Ancak diğer memleketlerde Cerrahi İplikler sıvı emme bakımından kulcal olan veya olmayan -Kapiler, Non Kapiler- diye iki cins yapılır. Türkiye'de de Non Kapiler Cerrahi İpliğin bazan arandığı hem hastanelerdeki tatbikattan hem de Sağlık Bakanlığının bizden kontrolunu istemesinden anlaşıldığından, bu özellik modifiye ettiğimiz aşağıdaki metod ile aranmıştır.

Kılcallık Aranması : İplik çilesinin içinden ve üç ayrı yerinden pens ile tutularak 15 'er cm'lik üç parça kesilir, uçları hafifçe tiftiklenir. Bis dereceli cam ölçeğe $1 / 1000$ metilen mavisi çözeltisi knmor. (Iplikimer sivah jse bir ucundan $10 \mathrm{~cm}$. mesafede beyaz hidrofil pamuk ipliği ile birleșik bir düğüm yapılır.)

İpek ipliğin bir ucu (siyah ise düğümden $10 \mathrm{~cm}$. uzaktaki) metilen mavisine batmak üzere $5 \mathrm{~cm}$ 'si ölçeğe batırılır, diğer kısım dıșarda bırakılır. Șekil 4. Beș saat içinde ipliğin dıștaki kısmı 
(siyah ise dügüumdeki beyaz pamuk ipliği) maviye boyanmamalıdir,

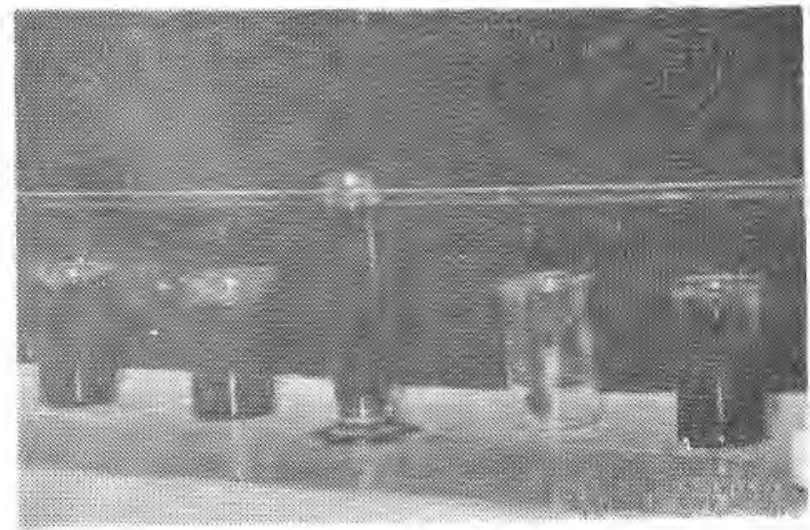

Șekii 4. Kılcallık tayinı

Sonuçlar : Pamuklar: Muayenelerden alınan sonuçlar Tablo 4a da toplanmıștır.

\section{Türk Farmakopesine göre Pamukların Kontrol Sonuçları :}

Klorï : Kontrol edilen 23 ayrı pamuktan (No. 9, 11, 13, 15, $17,19,20)$ yedisinde ( $\% 30)$ Türk Farmakopesi Standardından fazla klorür iyonu bulunmuştur.

Hidrofillik (Suya batma hizı) : 23 numuneden 7 (\% 30) tanesi Türk Farmakopesi'ne uygun bulunmamıștır. Bunlardan 6 tanesi serbest piyasada, yani Eczane ve Bakkallardan alınandır. Yüzde ile ifade edilir ise -piyasada satılanları \% 46'sı Ofisinal Hidrofillik özelliği göstermemektedir.

Bu yüzde 46 nun \% 13'ü ise (15 pamuktan ikisi) hiç Hidrofil olmayıp yağı alınmamış pamuktur. Fakat ambalâjları üzerinde Hidrofil -Ofisinal Pamuk olduğu yazılmaktadır.

Yabanci Lifler: Muayene edilen Pamuklardan 4 tanesinde yabancı lif tesbit edilmiștir. Yabancı lif oranı ise \% 50 bulunmuştur.

Yabancı Lif olarak Selluloz Pamuğu ilâve edilmiștir. Katkılı Pamukların \% 70'i hastane ve müiesseselere mubayaa edilmek üze- 
re verilmiștir. Piyasada ise kanunî takip sonucu olarak, ancak bir numune katkılı bulunmuştur. Silâhlı Kuvvetler hariç birçok diğer müesese de muayene edilmeden ve hiç bir șartnameye dayanmadan ișlem yapılması katkılı pamuk alınmasına neden olmaktadır denilebilir.

Genel bir bakıșla piyasadaki (bizim topladığımız) Hidrofil Pamuklarm \% 75'i -(Türk Kodeksi) Türk Farmakopesine uygun özellik göstermemektedir. Halbuki bu pamukların etiketlerinde Türk Kodeksine uygun oldukları yazılıdır. Aynı firmaya ait olan fakat değișik yerlerden alınan numuneler değișik vasıf gösterebilmektedir, Örneğin, No. 11 numunenin suya batma hızı (suyu emebilme yeteneğini gösterir - Hidrofillik) uygun olduğu halde ayn firmanin No. 18 -numunesi yağlı- suya hiç batmayan - hidrofil olmayan bir pamuktur.

Yüzey Etken Maddeler: Pamuklarin imalât esnasinda kuyu suyu ve nadiren de şehir suyu ile yıkanmasının çok masraflı olması ve şehir suyunda klor ve kuyu suyunda çok kalsiyum bulunması nedeni ile ve yüzey etken maddelerinde (deterjan) yağ kalıntılarnı daha kolay çıkarması dolayısı ile memleketimizde de bu yıkama usulune baş vurulmuștur.

Ancak, A. F. (2) ve D. A. B. (3), F. K. (6), I. F. (8) yüzey etken maddenin kendi kalıntısını da sınırlamaktadır. Bu muayene henüz T. K. (1)'de yoktur. Türk Farmakopesine ilâve edilmesi çok faydalı olacaktır. Çünkü, fazla miktardaki yüzey etken maddeler allerjik reaksiyonlara sebep olmakta ve hatta kanin koagulasyonuna zararli etki yapabilmektedir.

Yaptığımız kontrollar, Șekil 5., piyasadaki hidrofil pamukların \% 53'ünün Farmakopeler sınırlarından çok yüzey etken madde tașıdıklarını göstermiştir.

Cerrahi İpek İplikler : Hastane ve piyasada çoğunlukla örgülü tip bulunmaktadır. Șekil 6. Bir Firmanın da bükümlü yaptığı saptanmıştır. 


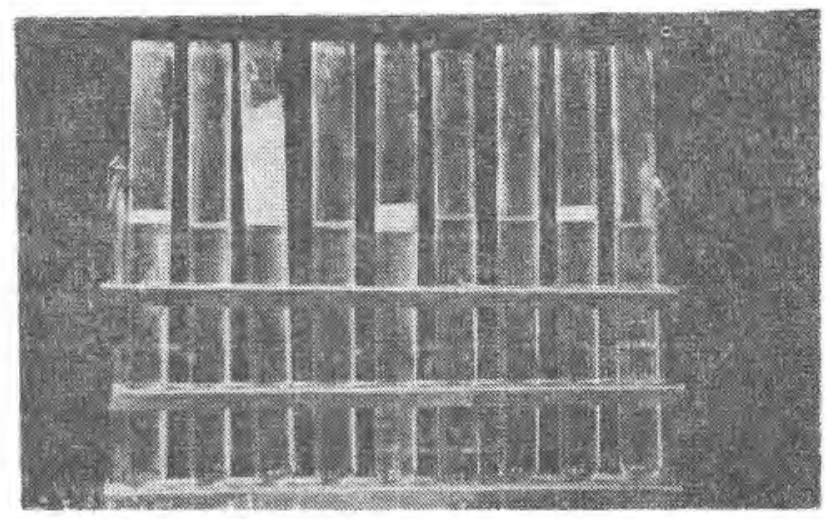

Șekil 5

Üzerinde çalıșılan cerrahi ipek iplikler; Ankara Yüksek İhtisas Hastanesi, A. Ü. Tıp Fakültesi Hastanesi, Hacettepe Tip Fakültesi Hastanesi, Gülhane Askerî Tıp Akademisi, Sosyal Sigortalar Hastanesi, Sağlık ve Sosyal Yardım Bakanlığı Muayene numunesi ve M.S.B. Lv. A. Muayene Komisyonu Genel Bșk. lığı ve Ankara ve İstanbul piyasasından alınmıștır.

Tanıma : Avrupa Farmakopesinin Iyotlu Potasyum Iyodür çözetıst ne ipeğin verdiği soluk sarı renk karakteristik bulunmamış-

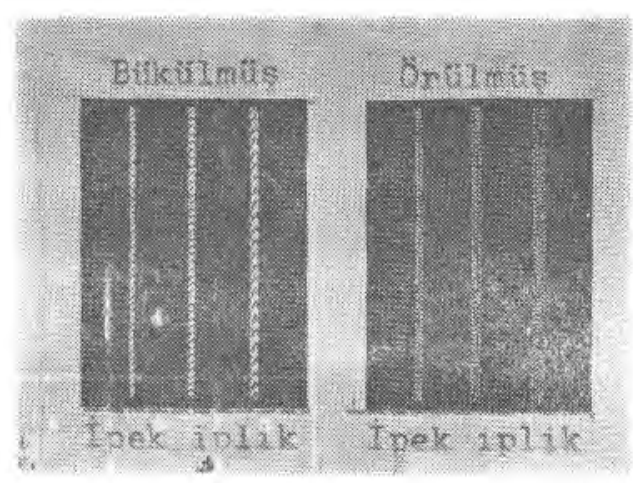

Spekil 6 
tır. Çünkü, katkı maddelerinden meselâ, Nylon'da aynı rengi vermektedir.

Tanıma için Mikroskop muayenesinden sonra Tablo 4'deki çözünme testlerinin en uygun olduğunu saptamış bulunuyoruz.

Uzunluk: Genellikle Farmakopelerin \% 5 tolerans sinırları içersinde bulunmușlardır.

Çap : Üzerinde çalıştığımız 4 tip yaklaşık 40 ayrı numara ve 200 çileden alınan sonuçlar Tablo 5, 6, 7, 8'de görülmektedir.

Standartların ortalama karșılıkları da Tablo IX'da gösterilmiștir.

$$
\text { Tablo - V }
$$

A Marka Cerrahi İpek Ípliklerle Yapılan Çap Tayinleri

\begin{tabular}{|c|c|c|c|c|c|c|c|c|c|c|c|c|}
\hline \multirow{2}{*}{$\begin{array}{l}\text { çile } \\
\text { Adedi }\end{array}$} & \multirow{2}{*}{$\begin{array}{l}\text { Cap } \\
\text { Numa- } \\
\text { ralari }\end{array}$} & 1 & 2 & 3 & 4 & 5 & 5 & 7 & 8 & 9 & 10 & \multirow[t]{2}{*}{ Ortalama } \\
\hline & & \multicolumn{10}{|c|}{ Bulunan caplar milimetre olarak } & \\
\hline 5 & 410 & 0.31 & 0.29 & 0.29 & 0.29 & 0.29 & 0.30 & 0.29 & 0.30 & 0.29 & 0.29 & 0.294 \\
\hline 5 & $3 / 0$ & 0.46 & 0.45 & 0.43 & 0.43 & 0.43 & 0.44 & 0.43 & 0.45 & 0.43 & 0.43 & 0.438 \\
\hline 5 & 210 & 0.48 & 0.48 & 0.49 & 0.49 & 0.47 & 0.47 & 0.47 & 0,47 & 0,46 & 0.45 & 0.473 \\
\hline 5 & $1 / 0$ & 0.46 & 0.44 & 0.42 & 0.43 & 0.44 & 0.43 & 0.42 & 0.44 & 0.42 & 0.45 & 0.433 \\
\hline 5 & 1 & 0.62 & 0.59 & 0.63 & 0.62 & 0.62 & 0.59 & 0.61 & 0.62 & 0.61 & 0.60 & 0.611 \\
\hline 5 & 2 & 0.65 & 0.63 & 0.63 & 0.64 & 0.63 & 0.63 & 0.64 & 0.63 & 0.62 & 0.63 & 0.633 \\
\hline 5 & 3 & 0.69 & 0.71 & 0.70 & 0.70 & 0.69 & 0.69 & 0.70 & 0.71 & 0.72 & 0.69 & 0.639 \\
\hline 5 & 4 & 0.77 & 0.76 & 0.77 & 0.76 & 0.75 & 0.79 & 0.76 & 0.75 & 0.77 & 0.75 & 0.763 \\
\hline 5 & 5 & 0.74 & 0.72 & 0.80 & 0.79 & 0.80 & 0.79 & 0.79 & 0.75 & 0.78 & 0.74 & 0.740 \\
\hline 5 & 6 & 0.78 & 0.82 & 0.81 & 0.84 & 0.83 & 0.81 & 0.81 & 0.81 & 0.90 & 0.81 & 0.832 \\
\hline 5 & 7 & 0.95 & 0.93 & 0.92 & 0.95 & 0.96 & 0.97 & 0.94 & 0.95 & 0.97 & 0.97 & 0.951 \\
\hline
\end{tabular}




$$
\text { Tablo - VI }
$$

C Marka Cerrahi İpliklerde Yapılan Çap Tayinleri

\begin{tabular}{|c|c|c|c|c|c|c|c|c|c|c|c|c|}
\hline \multirow{2}{*}{$\begin{array}{l}\text { Çile } \\
\text { Adedi }\end{array}$} & \multirow{2}{*}{$\begin{array}{l}\text { Cap } \\
\text { Numa. } \\
\text { ratari }\end{array}$} & 1 & 2 & 3 & 4 & 5 & 6 & 7 & 8 & 9 & 10 & \multirow{2}{*}{ Ortalama } \\
\hline & & \multicolumn{10}{|c|}{ Bulunan caplar mitimetre olarak } & \\
\hline 5 & 310 & 0.25 & 0.27 & 0.27 & 0.26 & 0.27 & 0.27 & 0.27 & 0.27 & 0.24 & 0.26 & 0.263 \\
\hline 5 & 210 & 0.29 & 0.25 & 0.25 & 0.31 & 0.24 & 0.30 & 0.25 & 0.25 & 0.26 & 0.27 & 0.267 \\
\hline 5 & 0 & 0.32 & 0.29 & 0.33 & 0.35 & 0.29 & 0.31 & 0.33 & 0.32 & 0.36 & 0.35 & 0.325 \\
\hline 5 & 1 & 0.47 & 0.46 & 0.48 & 0.47 & 0,46 & 0.47 & 0.45 & 0.49 & 0.47 & 0.48 & 0.470 \\
\hline 5 & 2 & 0.46 & 0.47 & 0.45 & 0.49 & 0.48 & 0.49 & 0.48 & 0.49 & 0,48 & 0.47 & 0.473 \\
\hline 5 & 3 & 0.50 & 0.56 & 0.50 & 0.55 & 0.53 & 0.52 & 0.46 & 0.46 & 0.48 & 0.47 & 0.503 \\
\hline 5 & 4 & 0.72 & 0.68 & 0.70 & 0.74 & 0.78 & 0.67 & 0.69 & 0.71 & 0.74 & 0.75 & 0.718 \\
\hline 5 & 5 & 0.68 & 0.72 & 0.71 & 0.76 & 0.74 & 0.76 & 0.73 & 0.75 & 0.75 & 0.68 & 0.728 \\
\hline 5 & 6 & 0.71 & 0.77 & 0.82 & 0.66 & 0.70 & 0.68 & 0.76 & 0.77 & 0.72 & 0.76 & 0.735 \\
\hline 5 & 7 & 0.75 & 0.77 & 0.75 & 0.74 & 0.67 & 0.79 & 0.78 & 0.76 & 0.71 & 0.74 & 0.746 \\
\hline
\end{tabular}

Tablo - VII

G Marka Cerrahi Ípliklerde Yapılan Çap Tayinleri

\begin{tabular}{|c|c|c|c|c|c|c|c|c|c|c|c|c|c|}
\hline \multirow{2}{*}{$\begin{array}{c}\text { Cile } \\
\text { Ade dI }\end{array}$} & $\begin{array}{c}\text { Cap } \\
\text { Numa- } \\
\text { ralari }\end{array}$ & \multicolumn{7}{|c|}{ Bulunan çaplar milimetre olarak } & \multicolumn{1}{c|}{ Ortalama } \\
\hline 5 & $5 / 0$ & 0.24 & 0.25 & 0.24 & 0.29 & 0.23 & 0.25 & 0.26 & 0.25 & 0.27 & 0.24 & 0.252 \\
\hline 5 & 2 & 0.49 & 0.41 & 0.40 & 0.39 & 0.38 & 0.41 & 0.40 & 0.42 & 0.38 & 0.36 & 0.398 \\
\hline 5 & 3 & 0.49 & 0.48 & 0.57 & 0.46 & 0.47 & 0.48 & 0.45 & 0.46 & 0.54 & 0.52 & 0.492 \\
\hline 5 & 4 & 0.50 & 0.47 & 0.49 & 0.48 & 0.48 & 0.48 & 0.49 & 0.48 & 0.46 & 0.47 & 0.480 \\
\hline 5 & 5 & 0.58 & 0.60 & 0.54 & 0.60 & 0.67 & 0.60 & 0.59 & 0.58 & 0.58 & 0.57 & 0.591 \\
\hline 5 & 6 & 0.65 & 0.62 & 0.68 & 0.67 & 0.63 & 0.66 & 0.66 & 0.62 & 0.65 & 0.68 & 0.652 \\
\hline 5 & 7 & 0.71 & 0.70 & 0.69 & 0.70 & 0.68 & 0.68 & 0.69 & 0.66 & 0.67 & 0.70 & 0.688 \\
\hline
\end{tabular}


Tablo - VIII

T Marka Cerrahi İpliklerde Çap Tayinleri

\begin{tabular}{|c|c|c|c|c|c|c|c|c|c|c|c|c|}
\hline \multirow{2}{*}{$\begin{array}{l}\text { Çile } \\
\text { Adedi }\end{array}$} & \multirow{2}{*}{$\begin{array}{l}\text { Cap } \\
\text { Numa- } \\
\text { ralari }\end{array}$} & 1 & 2 & 3 & 4 & 5 & 6 & 7 & 8 & 9 & 10 & \multirow{2}{*}{ Ortalama } \\
\hline & & \multicolumn{10}{|c|}{ Bulunan çaplar milimetre olarak } & \\
\hline 5 & 410 & 0.28 & 0.30 & 0.27 & 0.28 & 0.26 & 0.24 & 0.25 & 0.24 & 0.30 & 0.30 & 0.272 \\
\hline 5 & $3 / 0$ & 0.41 & 0.40 & 0.38 & 0.36 & 0.43 & 0.40 & 0.37 & 0.36 & 0.41 & 0.42 & 0.384 \\
\hline 5 & 210 & 0.40 & 0.38 & 0.37 & 0.38 & 0.42 & 0.39 & 0.37 & 0.36 & 0.37 & 0.44 & 0.388 \\
\hline 5 & 0 & 0.75 & 0.74 & 0.63 & 0.64 & 0.66 & 0.64 & 0.71 & 0.72 & 0.57 & 0.60 & 0.666 \\
\hline 5 & 1 & 0.61 & 0.55 & 0.55 & 0.53 & 0.54 & 0.53 & 0.57 & 0.53 & 0.52 & 0.53 & 0.546 \\
\hline 5 & 2 & 0.49 & 0.52 & 0.43 & 0.40 & 0.47 & 0.46 & 0.48 & 0.50 & 0.52 & 0.53 & 0.480 \\
\hline 5 & 3 & 0.43 & 0.44 & 0.42 & 0.44 & 0.42 & 0.45 & 0.42 & 0,43 & 0.43 & 0.44 & 0.432 \\
\hline 5 & 4 & 0.83 & 0.85 & 0.79 & 0.78 & 0.80 & 0.85 & 0.81 & 0.81 & 0.62 & 0.68 & 0.782 \\
\hline 5 & 5 & 0.75 & 0.73 & 0.75 & 0.74 & 0.74 & 0.72 & 0.79 & 0.77 & 0.74 & 0.73 & 0.746 \\
\hline 5 & 6 & 0.92 & 0.93 & 0.76 & 0.78 & 0.84 & 0.80 & 0.75 & 0.81 & 0.86 & 0.81 & 0.828 \\
\hline 5 & 7 & 0.94 & 0.87 & 0.95 & 0.99 & 0.95 & 0.87 & 0.87 & 0.95 & 0.89 & 0.91 & 0.919 \\
\hline
\end{tabular}

Tablo IX.

ipek ipliklerde Avrupa farmakopesi ve U.S.P. ortalama çap karșilıkları

\begin{tabular}{lcll}
$\begin{array}{c}\text { A.F. } \\
\text { No. }\end{array}$ & U.S.P. & \multicolumn{2}{c}{ Ortalama Cap } \\
& No. & mm. \\
0.1 & & A.F. & U.S.P \\
0.3 & $10 / 0$ & 0.019 & 0.019 \\
0.5 & $9 / 0$ & 0.039 & 0.032 \\
0.7 & $8 / 0$ & 0.056 & 0.045 \\
1 & $7 / 0$ & 0.080 & 0.064 \\
1.5 & $6 / 0$ & 0.120 & 0.090 \\
2 & $5 / 0$ & 0.170 & 0.127 \\
2.5 & $4 / 0$ & 0.220 & 0.178 \\
3 & $3 / 0$ & 0.270 & 0.229 \\
4 & $2 / 0$ & 0.350 & 0.292 \\
5 & $1 / 0$ & 0.450 & 0.370 \\
6 & 1 & 0.550 & 0.445 \\
7 & 2 & 0.650 & 0.521 \\
8 & 3 & 0.75 & 0.597 \\
& 4 & 0.85 & 0.673 \\
& 5 & - & 0.762 \\
& 6 & - & 0.864 \\
& 7 & - & 0.965
\end{tabular}


Sonuçlar aşağıda dört eğri halinde (Eğri 1, 2, 3, 4) de gösteril-
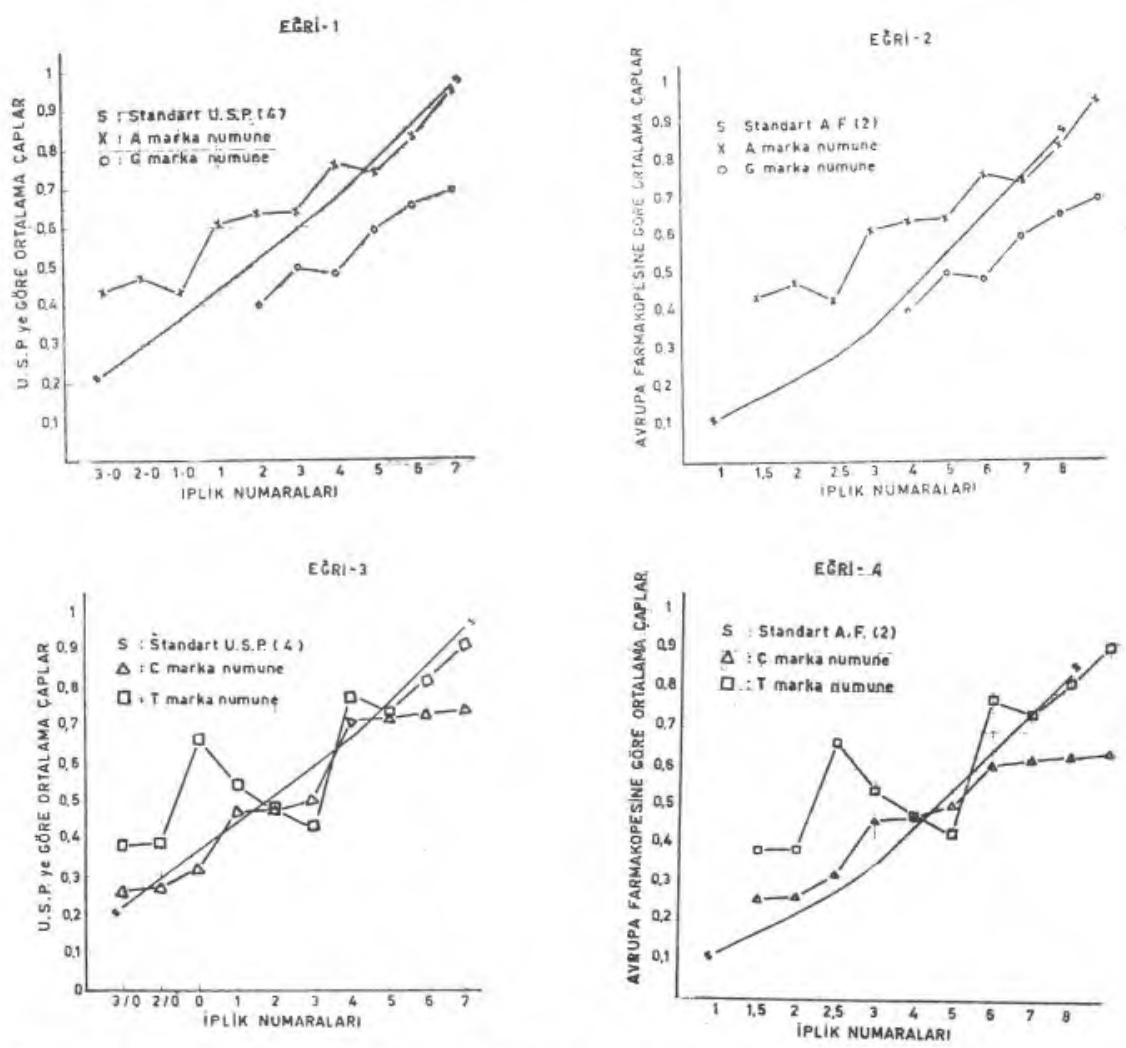

miștir. Bu eğrilerde A.F. (2), U.S.P. (4) standart çapları muntazam bir eğim göstermektedir. Numunelerinde bu standart eğrilere yakın bir paralellik göstermesi beklenirdi.

Halbuki eğriler, numune çaplarının genellikle büyük numaralarda standart eğrilere yaklaşım gösterdiğini, küçük numaralarda ise istenilen paralellikten büyük sapmalar yaptığını kanıtlamaktadir.

\section{Yabancı Lifler ve Oranı :}

Mikroskobik muayene ile bir çok numunenin karıșık elyaftan yapıldığı tesbit edilmiş ve durumu kesinlikle saptamak için Tablo 4'de (9) bildirilen kimyasal ayraçlarla kontroller tekrar edilmiştir. 
a) Yabancı liflerin genellikle bükümlü olarak ipek örgünün içine gömüldüğü Resim 2-3 tesbit edilmiștir.

b) Çözüiü _ kimyasal ayraçlarda ipek örgü çözününce,'içinden hiç çözünmemiș yabancı lif bükülmüș iplerden yapılı olarak meydana çıkmaktadır.

c) Yabancı liflerin Poliamid olduğu (Nylon sınıfı) tesbit edilmiştir.

d) Üzerinde çalıșılan - hastane ve piyasa Cerrahi İpek İpliklerinden yalınız T markanın Poliamid ile karıșık olduğu anlaşılmıștır.

e) Poliamid ile karıștırılmış Cerrahi İpek İpliklerdeki yabancı elyaf oranı numaralarına göre Tablo-10'da görülmektedir.

Tablo X.

Cerrahi iplik numaralarına

göre genel katkı oranı

\begin{tabular}{|c|c|}
\hline $\begin{array}{c}\text { Iplik } \\
\text { No }\end{array}$ & $\begin{array}{c}\text { Katkı Oranı } \\
\%\end{array}$ \\
\cline { 1 - 2 } & \\
$4-0$ & 35 \\
$3-0$ & 19 \\
$2-0$ & 13 \\
$1-0$ & 15 \\
1 & 28 \\
2 & 20 \\
3 & 15 \\
4 & 9 \\
- & 27 \\
6 & 14 \\
7 & 13 \\
\hline
\end{tabular}

Kılcallı : Șekil 4'de görülen modifiye kendi metodumuzla ve Amerikan -non kapiler- standart ipliklerle yaptığımız karșılıklı muayenelerde Türkiye'de imâl edilen (bizim hastanelerden ve piyasadan topladığımız) bütün cerrahi ipek ipliklerin renkli-renksiz kapiler olduğu saptanmıştır.

Ekstraksiyonla almabilen boyalar : Bir firmaya ait siyah ipek cerrahi iplikler U.S.P. ye uygun bulunmamıştır. 
Tablo XI. Cerrahi Ipek İpliklerde Avrupa Farmakopesi ve U.S.P. Ortalama Direnç Karșılıkları

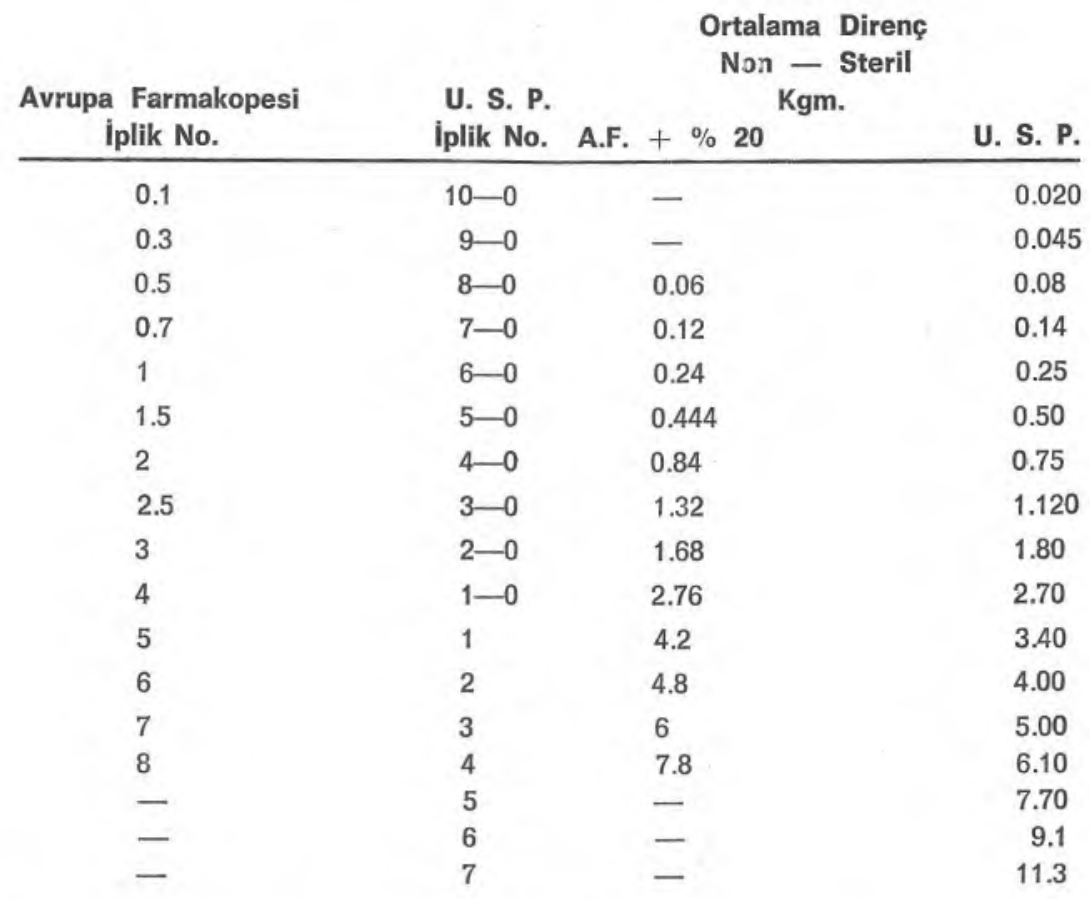

NOT : A.F. Basit Düğüm ile steril ipliklerde direnç tayin eder.

U.S.P. Cerrahi Düğüm ile non steril ipliklerde direnç tayin eder.

Direnç Testleri : Sterilize edilmemiş iplikler üzerinde yapılmıștır. A.F. ve U.S.P. düğüm şeklinde ayrıldıklarından çalışmamızda ayn iplik üzerinde hem basit hemde cerrahi düğ̈üm ile direnç testi yapılmıştır. Bu testlerin her iki usule göre bulunması lazım gelen değerleri Tablo 11'de ve numunelerde bulunan dirençlerde Tablo-12'de gösterilmiștir.

Tablo-10'daki A.F. kıymetleri U.S.P. kaidesine göre yüzde 20 artırılarak yapılmıștır. Böylece bütün ipliklerin --bulunan değerleri non steril ipliklerin göstereceği standartlarla karșılaștırılmıștır. 
Hidrofil Pamuk ve Cerrahi İliklerin Kalite Kontrolları

Tablo - XII

Cerrahi İpliklerin Ortalama Dirençleri

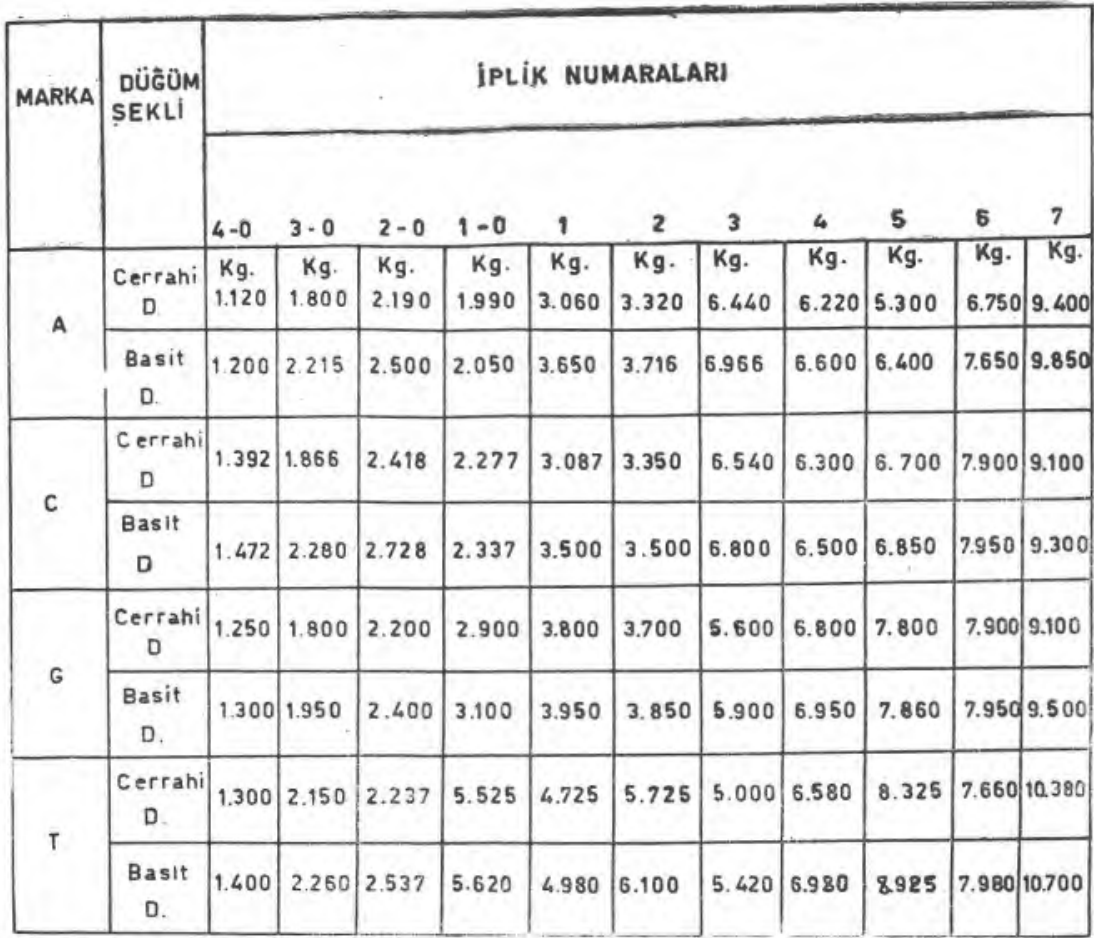

Sonuçların Tablo-12'de görülen değerleri asağıda ayrıca eğriler halinde de açıklanmıștır. Eğri 5, 6, 7, 8). Bu eğrilerde Farmakope standartları kalın çizgi ile görülmektedir.
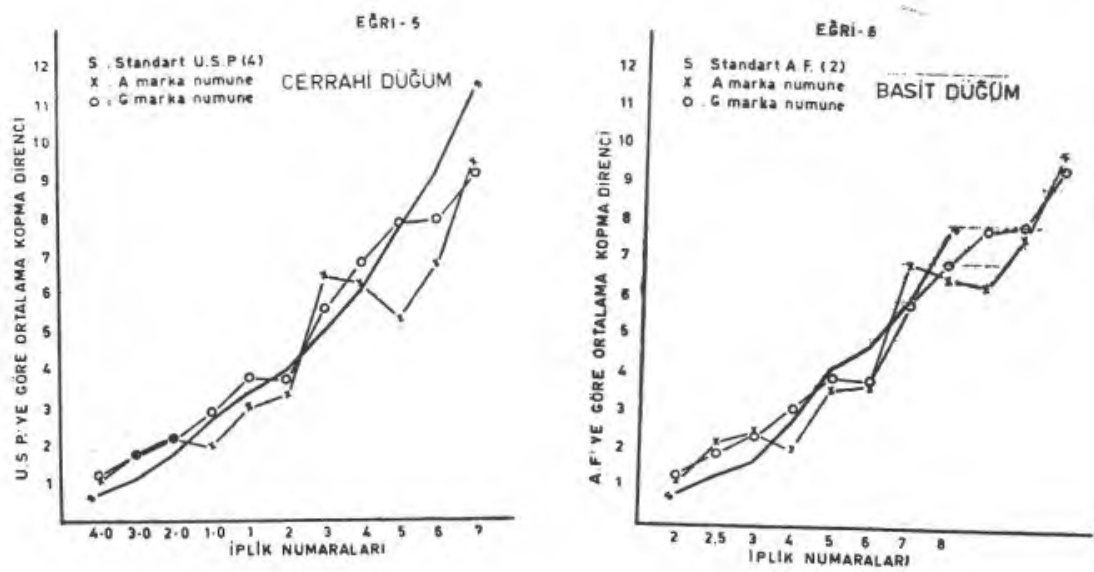

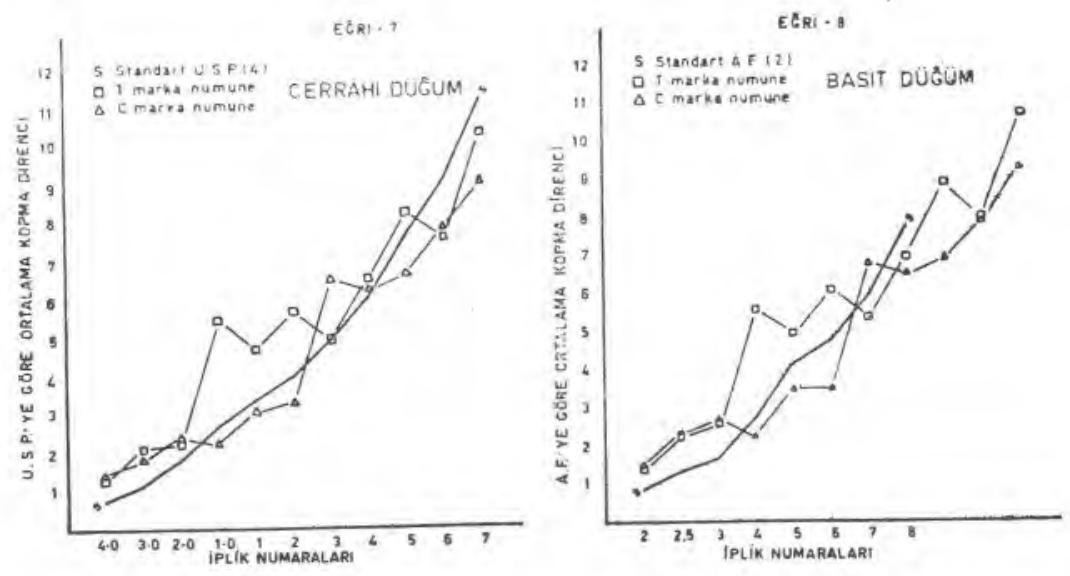

Eğrilerde görüldüğü üzere genellikle dirençler standartlara yakın değerler göstermekle beraber; $\mathrm{T}$ markalılarda küçük numaralarda; A ve G markada büyük numaralarda fazla sapmalar bulunmaktadir.

T marka katkı maddeleri tașıdığına göre bu katkı maddesinin dirençe etkisi katkı oranı ile alâkalı görülmektedir. Șöyleki, katkı ile direnç bir oranda artmakta ve standardı bazı hallerde geçmektedir.

Direnç testinde - pandüllü Shopper tipi alet ile çalışırken özellikle örgülü ipliklerde şu ayrıcalık tespit edilmiștir. Saf ipek iplikler kopmada cerrahi düğüm veya basit düğüm ile - muntazam ve tek darbede kopma göstermektedir. İçerisinde yabancı iplik bulunan (bizim numunelerimizde Nylon iplik) örgülü ipek iplik tiplerinde -kopma iki darbede aralıklı olmaktadır. İki defada kopuș, bu tip iplikler için açık bir özellik olarak literatürde ilk defa tarafımızdan saptanmıştır.

Aynı ipliğin cerrahi dügüum ile gösterdiği değer basit düğüm ile gösterdiği değerden genellikle daha düşük bulunmuștur.

\section{TARTIS MA}

Türkiye'de ilk defa Hidrofil Pamuk ve İpek Cerrahi İplikler üzerinde bir kalite kontrolü araştırması yapılmıștır. Üzerinde araștırma yapılan Cerrahi malzeme Türkiye'de imâl edilmektedir. Bun- 
lardan Hidrofil Pamuk «Gossypium depuratum» adı ile monografi olarak Türk Farmakopesi 1974'e almmıștır. Cerrahi İplikler «Sutur ve Ligatur» Türk Farmakopesine henüz alınmamıștır. Hidrofil Pamuk Kontrolları, Türk Farmakopesine (1) göre ve bu Farmakopede olmayan muayeneler de Avrupa Farmakopesi (2), U.S.P. ve diğer literatüre göre yapılmıștır. 23 ayrı Hidrofil Pamuk numunesi (300 paket) uizerinde çalıșılmıș ve bu numuneler Gülhane As. Tip. Ak. sine kontrol için gönderilenler ile Hastaneler, Eczaneler, Ecza Depolan ve Úniversite Hastanelerinden toplanmıștır. Muayeneler sonunda alınan sonuçlar Tablo 4-A da toplanmıștir.

Kontrol edilen Hidrofil Pamuk numunelerinden Farmakopeler Standartlarına göre : \% 30'u fazla klorür göstermiştir. Piyasadan alman Hidrofil Pamukların \% 46'sı Farmakopeye uymayan az Hidrofillik göstermiș, \% 13 'ü de hiç hidrofillik göstermemiştir. Bu uygunsuz numunelerin ambalâjlari üzerinde de Türk Kodeksine göre Hidrofil oldukları yazılmış bulunmaktadır. Üzerinde araștırma yapılan Pamuklarda yabancı liflerde aranmıș ve özellikle Hastane ve Müiesseselere mubayaa edilen pamuklarda \% 50 oraninda vis. koz pamuğu denen -odun sellulozundan kimyasal yolla elde edilip, lifleri kesilerek hazırlanan suni pamuk tesbit edilmiştir.

Numunelerden piyasadan alınanlar içerisinden de bir tanesinde sun'i pamuk bulunmuştur. Türk Farmakopesi yabancı elyaf ve sun'i pamuğu kabul etmediğinden bu pamukların kanun diși bir durumda hazırlandıkları anlașılmaktadir.

T.S. Kuvvetleri haricinde birçok müesseselerin kontrolsuz pamuk mubayaaları bu katkı işlemine alan hazırlamaktadır. Sun'i pamuk (viskoz pamuğu) liflerinin sert olması, dokuda duyarlik yaratması v.b. gibi hassas, açık ve yaralı deri ve mukozaya temasında tıbbî sakmcaları olduğu nedeni ile Türk Farmakopesi, doğal pamuklarda yabancı elyafin bulunmamasını şart koşmuștur.

Ayrica numuneler üzerinde yapılan yüzey etken madde araştrrmalarında da numunelerin \% 53'ünde yüzey etken madde Şekil-5 tesbit edilmiştir. Yüzey etken maddeler dokuda duyarlik meydana getirmeleri ve yaralı dokuda kanın durması üzerinde zararlı etki göstermeleri nedeni ile aranmaktadurlar. 


\section{Araştırmamiz göstermiştir ki;}

a. Genellikle hastaneler ve piyasadan aldığımız Hidrofil Pamuk numunelerinin \% 75'i Türk Farmakopesi isteklerine uyar bulunmamıștur.

b. Hidrofil Pamukların piyasa kontrolü gerekli olduğu kadar sıka yapılmamaktadır.

c. Hidrofil Pamuklarda yabancı elyaf - özellikle selluloz pamuğu - aranmalıdır.

d. Hidrofil Pamuklarda yüzey etken maddeler aranmalıdır.

e. Türk Farmakopesi'ne yabancı elyaf arama metodları ve yüzey etken madde aranması ile sınırlan ilâve edilmelidir.

\section{Cerrahi İpek İplikler :}

Türkiye'de Cerrahi dikiş ipliklerinden -sutur ve ligatur- yallnız İpek Cerrahi İplik imâl edilmektedir. Bu nedenle Türk Silâhlı Kuvvetleri Hastanelerine, Sağlık Bakanlığı Hastanelerine, Sosyal Sigortalar Hastanelerine ve Fakülteler Hastanelerine satın alınacak ve alınmış olan yerli Cerrahi İpek İplikler ile piyasada (sıhhî malzeme depoları) mevcut Cerrahi İpek İpliklerden topladığımız 4 ayrı firmaya ait 40 tip 200 çile Cerrahi İpek İplik izzerinde kalite araştırması yapılmıştır.

Bu Ipek Cerrahi İpliklerin 3 firmaya ait olanları örgü şeklinde dokunmuş, bir firmaya ait olan ise büküilï olarak imâl edilmiştir.

Araștırmalar : Türk Farmakopesi (1) 1974 Cerrahi Íplikleri monografi olarak almadığından diğer Farmakopeler $(2-8)$ ve literatür (9-16) ve kendi çalıșmalarımız olan metodlara göre yapılmiștır. Farmakopelerde mevcut kontrol metodları Tablo-3'de gösterilmiștir.

Farmakopelerden yalınız A.F. (2) Ipek Cerrahi İlikler için tanuma testi vermiştir. Bu test spesifik -ipeğe özgü- bulunmamış ve sentetik diğer bazı elyafın da aynı renkleri verdiği tesbit edildiğinden kendi uygulamamız olan aşağıdaki metod ve Tablo-4'de görüi. len kimyasal çözücüler yardımı ile teşhisleri yapılmıștır. 
Numune Hipoklorit çözeltisi içerisinde ve oda isısında 15 dakika tutulur. Ipek tamamen çözünür. Geri kalan ipliklerde : Evvelâ mikroskopta yaklaşım kontrolii yapılır. Yabancı hangi lif olabileceği araştırılır. Sonra kurutulur ve yakılır, koku ve yanma șeklinden, mikroskopun düșündürdüğü katkı maddesi olup olmadığı incelenir. Bu deneyden sonra lifler-sıra ile așağıdaki çözüicüler ile muamele edilir.

Aseton (Asetat çözünür), formik asit (Nylon çözünür), hidroklorik asit (Asetat ve Nylon çözünür); sülfürik asit (Asetat, Nylon ve Viskoz Reyon çözünür) amonyum tiyosiyanat (Orlon çözünür).

Bu metodumuz ile, bir firmaya ait ve hastanelerden alman numunelerin hepsinde (bütün numaralarında - Onbir ayrı numara) piyasadan alman numunelerin ise yine ayn firmaya ait 10 ayr iplik numarasindan 8 ayrı numarada katkı olarak Poliamid bulunmuştur. Katık ipliklerin, hakiki ipek ile şu yönde karıștırıldığı saptanmıștır. Poliamid lifler iki üç lif büklümü olarak, örgü ipek ipliğin içine gömülmüștür. Diğer bir deyimle Poliamid büküm ipliği üzerine (Şekil-2) ipekten örgü yapılmıștır.

Ipek Cerrahí İpliklerin Poliamid karışım oranı -kendi uyguladığımız iki ayrı metod ile tayin edilmiștir.

a - Iplikler hipoklorid içersine atılmıș ve çözünmeyen kısım ayrilıp kurutulduktan sonra tartılmıștır.

b - Poliamid büklüm, belirli ölçümdeki İpek İplik içersinden çekilerek çıkarılıp - ölçülüup tartılmıștır (Şekil-3).

$\mathrm{Bu}$ ișlemler sonunda -üzerinde çalıștığımız 4 firmaya ait İpek Cerrahi Ipliklerden yalınız bir firmanın ipliklerinin Poliamid ile karıștırılmıș olduğu saptanmıștır. Bu ipliklerdeki Poliamid miktan Tablo-10'da görülmektedir.

Araștırmamızda bulduğumuz iplik çapları Tablo V, VI, VII, VIII ve Eğri 1, 2, 3, 4'de gösterilmiş ve Tablo-IX'da da A.F. (2), U.S.P. (4) standart çaplarının karşılaştırılması yapılmışıtır. Ùzerinde çalıştı̆̆ımız numuneler standartlara göre büyük sapmalar göstermektedir, Bunun, hekimin kullanacağı iplik kalınlığını seçmesi bakımından önemi büyüktür. Çap ölçmeleri her numaradan 5'er çi- 
le üzerinde en az üçer sayma yapmak üzere Mauser marka mekanik ölçü aleti ile yapılmıştır.

Kılcallık üzerinde yaptığımız araștırmalardan memleketimizde yapılan bütün ipek cerrahi ipliklerin kılcal olduğu anlașılmıștır. Șekil-4'de görüldüğü gibi kılcallık tarafımızdan geliștirilen, ölçüilü cam silindir içerisinde metilen mavisine daldirma metodu ile saptanmıștır.

Direnç testlerinin sonuçları Tablo-XII ve Eğri 5, 6, 7, 8'de görülmektedir. Direnç testleri A.F, (2)'ye göre basit dügüüm ile U.S.P. (4)'ye göre de yine aynı çilelerde cerrahi düğüm ile ve sterilize edilmemiş olarak yapılmıştır.

Test için pandüllü Shopper tipi alet kullanılmıștır. Eğrilerde açıkça görüldügüu gibi A, ve G. marka İpek Cerrahi İpliklerde büyük numaralarda, T marka ipliklerde ise küçük numaralarda standartlardan büyük sapmalar görülmektedir.

Basit düğüum ile bulunan dirençlerin Cerrahi Dügüümle bulunan dirençlerden daha yüksek olduğu tesbit edilmiștir. Poliamid katkıI 1 ipek cerrahi iplikler direnç testi esnasında iki darbede kopmaktadır. Halbuki, saf iplikler tek darbede (bir ağırlıkta) kopar.

Böyle iki darbede kopma orijinal bir durumdur ve tarafımızdan ilk defa literatüre sunulmaktadır. Kopuşta evvelâ diş örgü ipek kısmı kopmakta, ondan sonra hemen içteki Poliamid lif kopmaktadir.

Çalıșmalarımızdan aldığımız sonuçlara göre :

a. Memleketimizde; İpek Cerrahi İpliklerin bazıları etike tinde bildirmeden - saf ipekten yapılmayıp Poliamid ile karıştırilmış olarak imâl edilmektedir.

b. Ipek Cerrahi İplik imalâtının daha itinalı yapılması lâzımdir. Çünkü, çaplar standartlara uymamaktadır.

c. İmalâtın hangi Farmakope șartlarına göre yapıldı̆̆ı etiketlerinde bildirilmelidir. Böylece hekimler iplik numaralarmdan hangi kalınlıktaki ipliği kullandıklarmı kesinlikle bilmelidirler. 
d. Sağlık Kurumlarınca satın alınacak İpek Cerrahi Iplik ve Genellikle Cerrahi İpliklerin hangi Farmakope özelliklerine göre istendiği șartnamelerde bildirilmelidir.

e. Cerrahi ipliklerin piyasa kalite kontrollarının daha sık yapılması lüzumlu görülmektedir.

f. Türk Farmakopesi 1974'e Cerrahi İplikler monografi olarak ilâve edilmelidir.

\section{Ö Z E T}

Türkiye'de imal edilen ve hastahanelerde kullanllan pamuk ve cerrahi ipek ipliklerin kaliteleri üzerinde bir piyasa araştırması yapılmıştır,

Kullanılan idrofil pamuklardan bazlarının viscone-sellüloz pamuğu içerdiği saptanmıştır.

Cerrahi ipєk iplikler üzerindeki çalışmalarda özellikle çaplar, direnç ve yabancı lifler kontrol edilmiștir. Piyasadaki cerrahi ipek ipliklerin bazlarının Avrupa Farmakopesi ve U.S.P. nin verdiği numaralara göre çap sınırlarına uymadığ1 görülmüştür. Bu çalışmalarda Türkiye'de imâl edilmiş olan cerrahi ipek ipliklerin bazllarının saf olmadığı ve yabancı elyaf özellikle naylon ihtiva ettikleri saptanmiştır.

Bu tayinlerde bazı özel teknikler de kullanılmıştır. Türk Farmakopesine gerek hidrofil pamuk ve gerek cerrahi ipek iplik muayeneleri konusunda bazı ilâveler yapılması teklif edilmiştir.

\section{$S U M M A R Y$}

An investigation of the quality of Purified Cotton and Surgical silk suture made in Turkey has been Presented. For this purpose the test methods of the Turkish, European and U.S. Pharmacopoeia was used. Samples of purffied cotton and surgical silk suture has been collected from different hospitals and from private pharmacies and depots.

The results of this study has shown that some of the samples of Prufied cotton collected from the market were not of the 
pharmacopoeia's quaity. Some of the samples which were taken from the hospitals have been found an illegal mixture of cotton and viscone - cellulose cotton. This investigation has also revealed

Before the inclusion of surgical sutures to the Turkısh Pharmacopoeia as a monograph the Governement agency should ask for, from now on, the statement on the label of surgical sutures to which Pharmacopoeia was the suture manufactured.

$$
\text { L I T E R A T Ü R }
$$

1. Türk Farmakopesi 1974 - Türk Kodeksi - S.S.Y. Bakanlığı.

2. Deutsches Arzaneibuch, 7. Ausgabe (1968), Govi - Verlag,

3. European Pharmacopoeia, II (1971), Councıl of Europe.

4. The United States Pharmacopoeia XVIIII (1970),

5 Osterreıchısches Arzneibuch (1966).

6. Pharmacopée Française, IX edition (1972).

7. The British Pharmacopoeia (1973).

8. Pharmacopoeia Helvetica VII (1970).

9. İzü, E., - Genel ve Endüstriyel Farmasi II. (1974).

10. Technical Manual and year Book of the American Assoc. Text. Chem. Color. Vol 27. (1951).

11. Journal of the Textile Inst 42, 10 (1951).

12. Du Bont, Gaıstomer Serv. Nylon. 2, (1951).

13. Modern Plastıcs Encylopedia and Eng. Handbook.

14. Waltacth, P., Harris, M., Resersh. Lab. Fibers Properties (1963).

15. Kommentar Zur D.A.B. VII (1973).

16. Delonca., H., et. al, Helv. Act. Pharm 3, (1975), 